\title{
Managers Views on the Determinants of Cash Holdings: Evidence from Kenya
}

\author{
Constantine Barasa ${ }^{1}$, George Achoki ${ }^{1}$, \& Amos Njuguna ${ }^{1}$ \\ ${ }^{1}$ Chandaria School of Business, United States International University-Africa, Nairobi, Kenya \\ Correspondence: Constantine Barasa, Chandaria School of Business, United States International \\ University-Africa, P.O Box 24381-00100 Nairobi, Kenya. E-mail: bconie@yahoo.co.uk
}

Received: June 11, 2018

Accepted: July 7, 2018

Online Published: July 15, 2018

doi:10.5539/ijef.v10n8p172

URL: https://doi.org/10.5539/ijef.v10n8p172

\begin{abstract}
Cash is essential for firms to support their day-to-day operations, take care of uncertainties in future and to take advantage of profitable opportunities that arise. However, setting the optimal cash holding by firms is not an easy task for managers and continues to be a hotly debated subject especially after the latest development in the global financial system. Empirical evidence in Kenya on the subject is scant, and the purpose of the paper is to establish the determinants of cash holding among firms listed in Kenya's Nairobi Securities Exchange(NSE) from a manager's perspectives. 168 questionnaires were administered to senior and finance executives in 44 non-financial firms listed on NSE. The respondents agreed with the statements on the expected relationship between Cash holding and Interest rates and industry sector and disagreed with the constructs on size,levarage,cashflow and Market- to- book value (MTB). The results may point to some agency problem in Kenyan listed nonfinancial firms.
\end{abstract}

Keywords: cash holding, cash flow, firm size, leverage, market-to-book value

\section{Introduction}

\subsection{Background}

The marginal cost of holding cash is an opportunity cost of capital as a result of the low return on liquid assets (Morais \& Silva, 2013). Despite cash holding being a low return assets firms still hold it for several reasons. At its most basic use cash is needed for settlement of transactions as and when they fall due and therefore support the normal operations of the firm. Over and above the normal transactional needs, cash holding is justified on the basis that because of the dynamic nature of the market place there are surprises that may need to be taken care off and therefore firms hold some cash for a "rainy" day in the process this helps firms reduce the risk of bankruptcy or financial stress (Almeida, Campello, \& Weisbach, 2004). There are also some opportunities that come along the way in the form of value adding projects and firms with a healthy cash reserve are better placed to take advantage of. It is not cheap to raise funds externally whether debt or equity thus in order to minimize these costs firms choose to hold internally generated cash. Myers (1977) developed the tradeoff theory which seeks to optimize the cost of holding cash against the benefits accrued from such cash holding.

Myers and Majluf (1984) propose a theory of cash holding that is grounded in the firms financing structure. The pecking order theory states that when firms are faced with the issue of financing attractive investment projects they have a choice of using internal and external sources of finance. However because of market imperfections firms prefers to use internal sources (retained earnings) which are deemed cheap and readily available then debt and finally equity. Under this thinking then a firm does not have an optimal cash level that they aspire but rather will be dictated by investment opportunities available and the ease of obtaining external financing (Ferreira \& Vilela, 2004).

Due to the separation of management and ownership, the managerial agency theory holds that the relationship between managers and shareholders has the potential for many conflicts of interest (Jensen, 1986), with the controllers of a business not necessarily operating that business in the interests of shareholders (Pinkowitz et al., 2006) by retaining large cash reserves to be used at their own discretion (Al-Najjar, 2013).

According to the agency theory the actions of the managers may lead to destruction in a firm's value because if managers are left alone to run a company in their own best interests, they tend to waste resources on their agenda 
and projects (Dittmar \& Mahr-Smith, 2007), incurring agency costs. Due to the liquidity of cash, such a result is more likely to occur with cash than with any other firm assets (Powell \& Kent-Baker, 2010). The theory has further implications for the value of cash reserves because investors tend to believe that managers are likely to deploy cash reserves inefficiently, and investors, therefore, lower their valuations of cash holdings (Dittmar \& Mahr-Smith, 2007).

\subsection{Problem Statement}

Several studies on the international seen have sought to explain the firm characteristics that affect cash holding using the three theoretical models: the trade-off model (Myers, 1977) and the pecking order model (Myers \& Majluf, 1984) and the free cash flow theory (Jensen 1986). Within the three theoretical models a number of determinants of cash holding have been developed: Investment opportunities, firm size, leverage, dividend payments, corporate governance parameters (Board size, CEO duality, and ownership structure and investor protection mechanisms), cash flow volatility, credit rating, interest rates, and financial constraints among others. There has been no universal agreement in the result and also most of the studies have been carried out predominantly using secondary data and in developed markets.

Empirical evidence on the determinants of cash holdings among non-financial firms quoted on the Nairobi Securities Exchange is limited more so on those that takes into account the manager's perspectives. This paper therefore seeks to examine the determinants of cash holdings from the manager's lens therefore adding insights to the factors that determine the optimality of the cash holding among firms.

\subsection{Theoretical and Empirical Review}

\subsubsection{Trade-Off Theory}

Developed by Myers (1977), the trade-off theory states that firms set their optimal level of cash holdings by weighing the marginal costs and marginal benefits of holding cash. The trade-off theory of cash-holding behavior suggests that firms can find an optimal cash balance by trading off the costs and benefits of holding cash (Dittmar et al., 2003). With the benefits of holding cash relating to prudence, the ability to invest in profitable opportunities when external financing is limited, and a curtailment of costs compared with asset liquidation or raising outside financing (Ferreira \& Vilela, 2004) while the costs associated with holding cash are mainly related to opportunity costs incurred through failing to invest in positive net value projects (Opler et al., 1999).

Under the trade-off theory, some factors relating to firm characteristics influence firms' cash holding decisions, including the payment of dividends, size, leverage, cash flow and the availability of liquid assets to act as cash substitutes. Other factors include the existence of investment opportunities, cash flow uncertainty, and debt maturity. For instance, Ferreira and Vilela (2004) found support for the trade-off theory in EMU countries where they established that the available investment opportunities and cash flow uncertainty positively influenced cash holdings, while liquidity, size, and leverage negatively influence cash holdings. Powell and Baker (2010) found strong evidence for the trade off as a determinant in a survey of the views of 1,000 US CFOs on cash holdings. The results showed that $72 \%$ of the CFOs agreed with trade-off as a determinant for cash holdings, with strong support for precautionary factors and the availability of investment opportunities as determinants of cash-holding decisions.

The existence of financial constraints has been found to impact the target level of cash holding as predicted by the tradeoff theory (Almeida et al., 2004; Gryglewicz, 2011) as financial constraints introduce elements of uncertainty supporting the precautionary motive. Further, the tradeoff theory assumes managers are always acting in the best interest of the shareholders it has been argued that where managers do not necessarily act in such a manner the agency problem sets in and the cash holding patterns do not follow the tradeoff theory prediction (Saddour, 2006). Dittmar and Duchin (2010) argue that that firms actively rebalance their cash holdings, yet imperfectly, consistent with the presence of adjustment costs this may affect the working of the pure tradeoff theory.

Venkiteshwaran (2011) surveyed US firms and found evidence supporting trade-off theories in the firms' analyses of target cash-holding levels. The study found that over time, firms targeted optimum cash levels and exhibited trade-off behavior in their evaluation of the costs and benefits of retaining cash when selecting cash-holding levels.

\subsubsection{Pecking Order Theory}

The pecking order theory of Myers and Majluf (1984) states that companies seek to decrease their costs associated with asymmetric information in external financing by using sources of financing for investments in a 
particular order. Retained earnings are used first because they are the cheapest source, and when retained earnings are drained, enterprises resort to external funds in the form of debt financing, followed by equity (Ferreira \& Vilela, 2004). Debt financing is sought before equity financing because debt financing tends to have lower asymmetric information costs (Al-Najjar, 2013).

This theory suggests that firms do not have target cash levels, but instead, cash is used as a buffer between retained earnings and investment needs. Thus, when current operational cash flows are enough to finance new investments, firms repay debt and accumulate cash. When retained earnings are not enough to finance current investments, firms use the accumulated cash holdings and, if needed, issue debt. (Ferreira \& Vilela, 2004). Profitability and leverage are found to hold consequential significance for cash holdings under this theory (Al-Najjar \& Belghitar, 2011).

Under the pecking order theory, an optimum cash level is not sought by firms, but internal financing is preferred, and cash acts as a buffer to finance future investment needs (Ferreira \& Vilela, 2004). If cash flows are adequate to provide firm's investment requirements, the firm can use retained earnings to pay down debt, hold cash and pay dividends, in that order (Al-Najjar \& Belghitar, 2011). If cash flows are not adequate to provide for a firm's investment requirements, firms will lower dividends and cash holdings and issue debt (Ferreira \& Vilela, 2004).

Ferreira and Vilela (2004) examined many of the predicted relationships between determinants and levels of cash holdings and also found evidence to support the pecking order theory. For instance, a high level of available investment opportunities and cash flows led to greater levels of cash holdings, while leverage and the availability of liquid assets had a negative impact, consistent with pecking order predictions. The researchers concluded that pecking order theory offers an important explanation for the determinants of cash holdings. Al-Makawi (2007) in a survey of the dividend policy of Jordanian firms, also found evidence for the pecking order theory. The maturity of the firm, firm size and profitability were all positively related to dividend policy, which it was argued was broadly consistent with pecking order theory.

\subsubsection{Free Cash Flow Theory}

Jensen's (1986) managerial agency theory of corporate cash holdings emphasizes the importance of corporate governance in the determinants of cash holdings and the possible adverse impacts of large cash holdings. Due to the separation of management and ownership, the theory holds that the relationship between managers and shareholders has the potential for many conflicts of interest with the controllers of a business not necessarily operating that business in the interests of shareholders (Pinkowitz et al., 2006) by retaining large cash reserves to be used at their own discretion (Al-Najjar, 2012).

According to the theory, the actions of managers could lead to destruction in value because if managers are left alone to run a company in their own best interests, they tend to waste resources on their agenda and projects (Dittmar \& Mahr-Smith, 2007), incurring agency costs. Due to the liquidity of cash, such a result is more likely to occur with cash than with any other firm assets (Powell \& Kent-Baker, 2010). The theory has further implications for the value of cash reserves because investors tend to believe that managers are likely to deploy cash reserves inefficiently, and investors, therefore, lower their valuations of cash holdings (Dittmar \& Mahr-Smith, 2007).

Under the managerial agency theory, empirical evidence would be expected to show that managers of a company are likely to stockpile cash reserves (Pinkowitz et al., 2006). Kalcheva and Lins (2007) found moderate empirical evidence for this assertion in their study utilizing managerial control rights data of over 5000 companies in 31 countries to investigate the relationship between control, corporate governance and cash holdings. The researchers found that companies with controlling managers tended to have higher cash reserves, and the correlation was even more significant where shareholder protection was weak. Whereas the free cash flow theory seems to point at managers as being influenced by selfish motive some studies indicate that managerial characteristics such as conservatism, prior professional experience and socialization impact their financial decision making (Dittmar \& Duchin, 2013).

\section{Method}

The study adopts a descriptive research design on a population of 44 non-financial firms listed on the Nairobi Securities Exchange (NSE). The choice of listed firms was based on the understanding that listed firms have to conform to standard listing requirements and are bound to be more transparent. The data from these firms were obtained through administration of questionnaires. The questionnaires we adopted in the study were those that were developed by Powel and Baker (2010) but slightly modified to achieve the objectives of the present study.

The survey questionnaire contained three sections with the first section of the questionnaire capturing the 
background information of the surveyed firms. The survey asked respondents to indicate their level of agreement or disagreement with each statement about corporate cash holdings in nonfinancial firms quoted at the NSE in general where $\mathrm{SD}=$ strongly disagree (1), $\mathrm{D}=$ disagree (2), $\mathrm{A}=$ Agree (3), and SA = strongly agree (4). The questioned covered the determinants of cash holding such as investment opportunity, firm size, leverage, cash flow, Industry and interest rates.The cover letter assured recipients that their answers would be completely confidential and released only in summary form. If the CFOs preferred not to respond to the survey personally, they were asked to give it to someone actively involved in their firm's liquidity decisions or to return the blank questionnaire. The questionnaires were physically delivered and collected from the firm's corporate head offices. The Primary data used in the study was collected between April and June 2015. 168 questionnaires were sent to 38 companies sampled for the study. The response rate obtained was $56 \%$ which is considered adequate (Mugenda \& Mugenda, 2003).

To measure the reliability of the questionnaire administered we adopted the Cronbach's alpha correlation coefficient which is used as a measure of the reliability of questionnaires. The results indicated that the Cronbach Alpha coefficient of the questionnaires were satisfactory (i.e. Alpha $=0.737$ ) and was closer to 1 which in the view of Sekeran (2003) is adequate for inferential purposes.

Besides examining the reliability of the questionnaire in obtaining the relevant information we examined the collected data to ensure that it was adequate and appropriate for inferential statistical tests such as the factor analysis. In line with that we performed two main tests namely; Kaiser-Meyer-Olkin (KMO) Measure of Sampling Adequacy and Barlett's Test of Sphericity. The results of the two tests are presented in Table 2 where the KMO statistic was which was significantly high for all the variables in the study; that is, greater than the critical level of significance of the test which was set at 0.5 (Field, 2000). In addition to the KMO test, Bartlett's Test of Sphericity was also highly significant. These results provide an excellent justification for further statistical analysis to be conducted.

Table 2. KMO sampling adequacy and bartlett's sphericity tests

\begin{tabular}{lcccc}
\hline \multicolumn{1}{c}{ Sampling Adequacy Tests } & Kaiser-Meyer-Olkin & Bartlett's Test of Sphericity & df & Sig. \\
\hline Market-to-Book Ratio & 0.726 & 429.804 & 15 & 0.00 \\
Firm Size & 0.574 & 47.845 & 3 & 0.00 \\
Leverage & 0.722 & 137.676 & 10 & 0.00 \\
Cash Flows & 0.629 & 130.612 & 6 & 0.00 \\
Interest Rates & 0.546 & 36.212 & 3 & 0.00 \\
Industry Specific Characteristics & 0.597 & 21.054 & 3 & 0.00 \\
\hline
\end{tabular}

\section{Results and Discussions}

This section presents information on the background information of the surveyed firms. The background information relates to the number of employees, firm size, position held by the respondents and their size. This section also presents inferential results of the manager's perspectives on the cash holding levels in their firms.

\subsection{Firm's Characteristics}

Of the firms surveyed, we established that 65 percent of them had more than 500 employees while the remaining 35 percent had between 100 and 500 employees with no firm having less than 100 employees. On the firm's turnover, we establish that 33 percent of the firms had an annual turnover of between one and five billion, 19 percent had an annual turnover of below one billion. Seven firms had a turnover of between 5- 10 billion. Four firms had a turnover of between 10 and 20 billion. The survey also indicated that three firms had an average turnover of between 20-30 billion and 30-50 billion respectively. Only four firms had an average turnover of above 50 billion on the research horizon.

On the cash ratio, Figure 1 shows the Cash Ratio trend for the non-financial companies from the year 2002 to 2013. The trend line indicates that cash ratio trend has been on the decline as indicated by a negative slope of the linear (cash ratio) trend line fitted to the cash ratio values over the period. However, we observe a cyclical increase in cash holding for non-financial firms that sort of peaks around the periods 2002, 2007 and 2013. These were election years, and it could be that firms shower up their cash balances due to uncertainty related to the electioneering period. The overall decline is puzzling as it seems not consistent with trends in cash holding in other markets where previous studies have indicated a general increase in cash holding. However as explained below in absolute terms there was an increase. 
The average cash holding is highest in 2005 at 7.9 percent and lowest in 2010 at 2.09 percent of average net assets. The sharp decline in 2010 can be attributed to the effects of the 2007/8 post-election violence in the country in that lead to an economic growth rate slowdown in the following two years with the GDP falling. Whereas the rise of average cash holding over the study period from an average of 6.8 percent in 2002 to 7.8 percent in 2013 doesn't appear dramatic, the 14.7 percent growth represents gradual growth in cash holding over time, and this compares with growth reported in other studies.

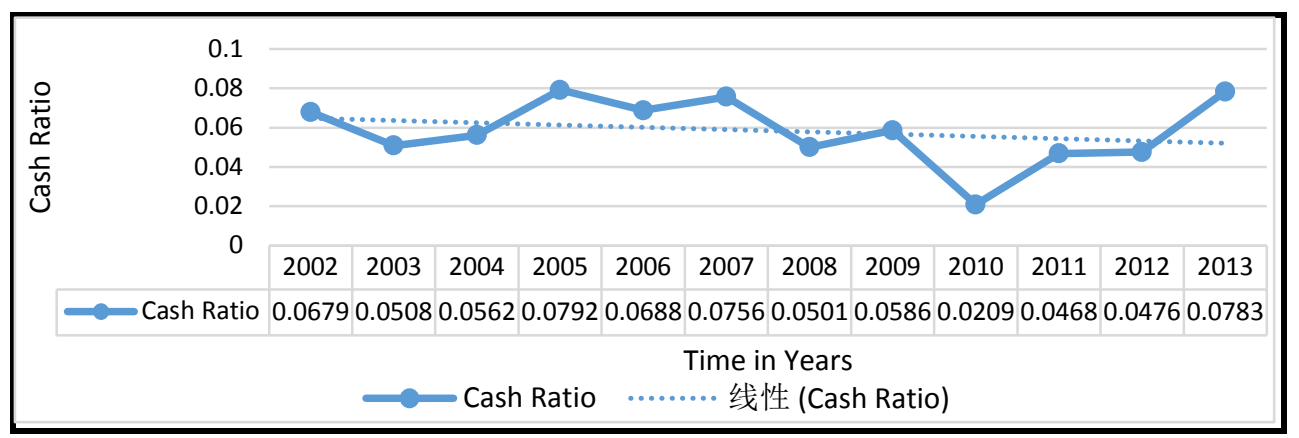

Figure 1. Cash ratio movements (2002-2013)

Figure 2 further shows the position held in the company by the respondent's interviewed. The majority of the respondents, accounting for 57 percent were either finance managers/chief accountants/financial controller. Further, the results indicated that 22 percent of those interviewed were the general manager or the chief finance officer and further 21 percent of them were managing directors.

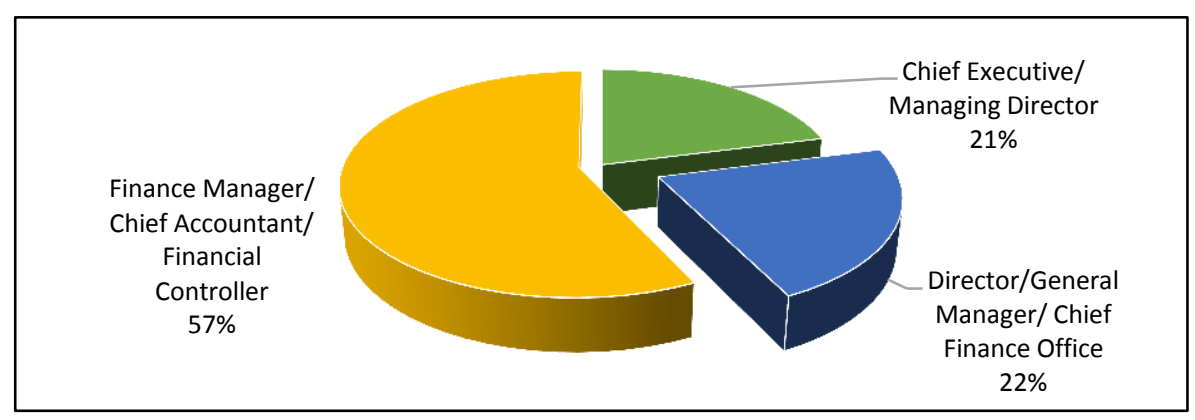

Figure 2. Position held of those interviewed

Figure 3 indicates the sectors from which the study was conducted. The results indicate that among all the surveyed firms' 24 percent were within the commercial sector, 18 percent in the automobile sector, 14 percent were in the energy and petroleum sector, 13 percent were in the construction sector 8 percent were in the agricultural sector, telecommunication industry and the investment sectors while another 7 percent of these firms were within the manufacturing sector.

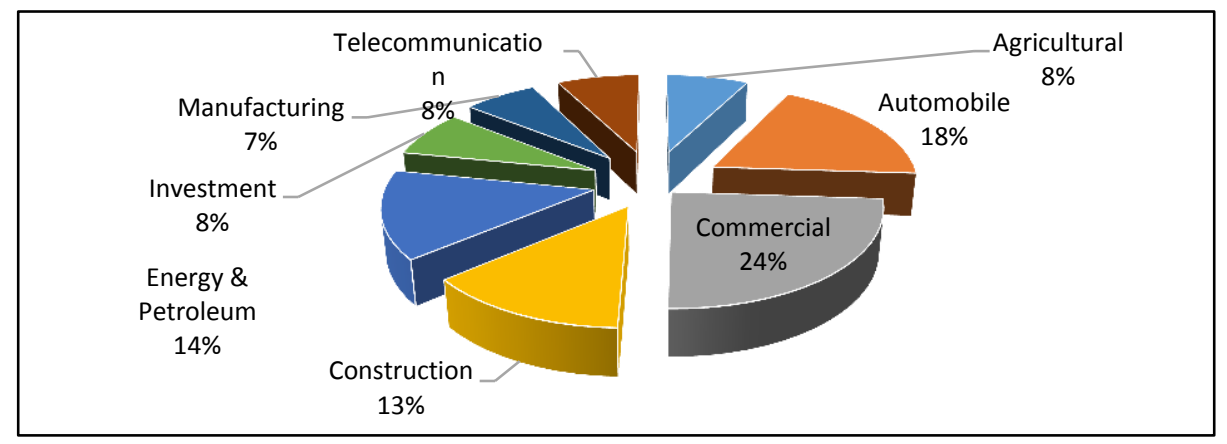

Figure 3. Sectors of operations 


\subsection{Sampling Adequacy and Reliability}

To examine whether the data collected was adequate and appropriate for inferential statistical tests such as the factor analysis, two main tests were performed namely; Kaiser-Meyer-Olkin (KMO) Measure of Sampling Adequacy and Barlett's Test of Sphericity. For a data set to be regarded as adequate and appropriate for statistical analysis, the value of KMO should be greater than 0.5 (Field, 2000). Findings in Table 3 showed that the KMO statistic was which was significantly high for all the variables in the study; that is greater than the critical level of significance of the test which was set at 0.5 (Field, 2000). In addition to the KMO test, Bartlett's Test of Sphericity was also highly significant. These results provide an excellent justification for further statistical analysis to be conducted.

Table 3. KMO sampling adequacy and bartlett's sphericity tests

\begin{tabular}{lcccc}
\hline \multicolumn{1}{c}{ Sampling Adequacy Tests } & Kaiser-Meyer-Olkin & Bartlett's Test of Sphericity & df & Sig. \\
\hline Market-to-Book Ratio & 0.726 & 429.804 & 15 & 0.00 \\
Firm Size & 0.574 & 47.845 & 3 & 0.00 \\
Leverage & 0.722 & 137.676 & 10 & 0.00 \\
Cash Flows & 0.629 & 130.612 & 6 & 0.00 \\
Interest Rates & 0.546 & 36.212 & 3 & 0.00 \\
Industry Specific Characteristics & 0.597 & 21.054 & 3 & 0.00 \\
\hline
\end{tabular}

\subsection{Managerial Perspectives on Firm's Cash Holdings and Market-to-Book Value}

We first examine the manager's perspectives on the relationship between market-to-book ratio and the level of cash holding where we establish that 21 percent of the managers are of the view that firms strive to hold optimal levels of cash that trade off the opportunity costs of holding too much cash against the trading costs of holding too little, 34.50 percent agreed that the firms with greater uncertainty in their future cash flows tend to hold more cash to prevent underinvestment in future profitable projects and 60.5 percent agreed that firms with abundant investment opportunities hold higher levels of cash to insulate future capital expenditures from the variability of internally generated cash flows. 19.3 percent agreed that firm prefer larger cash balances to provide them with more discretion in my firm's spending and capital expenditure decisions and a very low 9.3 percent agreed that firms with abundant investment opportunities hold excess cash to maintain their competitive positions. This finding is consistent with Baker and Powel (2010) who also reported results contrary to arguments by Baskin (1987), Froot (1993), and Chen et al. (2009) that firms hold excess cash for competitive reasons. We also established that 14.30 percent agreed that they held high cash balances because to support our share price.

Table 4. Descriptive statistics of effect of market to book ratio constructs

\begin{tabular}{|c|c|c|c|c|c|c|}
\hline Statement & $\begin{array}{l}\text { Strongly } \\
\text { Disagree }\end{array}$ & Disagree & Agree & $\begin{array}{l}\text { Strongly } \\
\text { Agree }\end{array}$ & Mean & Std. Dev \\
\hline $\begin{array}{l}\text { Firms strive to hold optimal levels of cash that trade off the opportunity } \\
\text { costs of holding too much cash against the trading costs of holding too } \\
\text { little }\end{array}$ & $46.20 \%$ & $32.80 \%$ & $9.20 \%$ & $11.80 \%$ & 1.87 & 1.01 \\
\hline $\begin{array}{l}\text { Firms with greater uncertainty in their future cash flows tend to hold more } \\
\text { cash to prevent underinvestment in future profitable projects }\end{array}$ & $5.00 \%$ & $60.50 \%$ & $20.20 \%$ & $14.30 \%$ & 2.44 & 0.80 \\
\hline $\begin{array}{l}\text { Firms with abundant investment opportunities hold higher levels of cash } \\
\text { to insulate future capital expenditures from the variability of internally } \\
\text { generated cash flows }\end{array}$ & $5.90 \%$ & $33.60 \%$ & $51.30 \%$ & $9.20 \%$ & 2.64 & 0.73 \\
\hline $\begin{array}{l}\text { I prefer larger cash balances to provide me with more discretion in my } \\
\text { firm's spending and capital expenditure decisions }\end{array}$ & $18.50 \%$ & $62.20 \%$ & $10.90 \%$ & $8.40 \%$ & 2.09 & 0.79 \\
\hline $\begin{array}{l}\text { Firms with abundant investment opportunities hold excess cash to } \\
\text { maintain their competitive positions }\end{array}$ & $21.00 \%$ & $69.70 \%$ & $1.70 \%$ & $7.60 \%$ & 1.96 & 0.73 \\
\hline We hold high cash balances because to support our share price & $2.50 \%$ & $83.20 \%$ & $6.70 \%$ & $7.60 \%$ & 2.19 & 0.60 \\
\hline Total & $16.52 \%$ & $57.00 \%$ & $16.67 \%$ & $9.82 \%$ & 2.20 & 0.78 \\
\hline
\end{tabular}

\subsection{Managerial Perspectives on Firm's Cash Holdings and Firm Size}

Table 5 shows that 21 percent agreed that they held less cash because my firm is large, 67.30 percent agreed that the Large firms have leverage with lenders and investors and are therefore able to hold less cash and 15.90 percent agreed that they held more cash when their company was small. The mean score for the responses was 2.10 which indicates that many respondents disagreed to the statements regarding firm size constructs. 
Table 5. Descriptive statistics of effect of firm size constructs

\begin{tabular}{|c|c|c|c|c|c|c|}
\hline Statement & $\begin{array}{l}\text { Strongly } \\
\text { Disagree }\end{array}$ & Disagree & Agree & $\begin{array}{l}\text { Strongly } \\
\text { Agree }\end{array}$ & Mean & $\begin{array}{l}\text { Std. } \\
\text { Dev }\end{array}$ \\
\hline I hold less cash because my firm is large & $46.20 \%$ & $32.80 \%$ & $9.20 \%$ & $11.80 \%$ & 1.87 & 1.01 \\
\hline $\begin{array}{l}\text { Large firms have leverage with lenders and investors and are } \\
\text { therefore able to hold less cash }\end{array}$ & $5.00 \%$ & $27.70 \%$ & $55.50 \%$ & $11.80 \%$ & 2.74 & 0.73 \\
\hline We held more cash when our company was small & $53.80 \%$ & $30.30 \%$ & $9.20 \%$ & $6.70 \%$ & 1.69 & 0.90 \\
\hline Total & $35.00 \%$ & $30.27 \%$ & $24.63 \%$ & $10.10 \%$ & 2.10 & $\mathbf{0 . 8 8}$ \\
\hline
\end{tabular}

\subsection{Managerial Perspectives on Firm's Cash Holdings and Leverage}

Table 6 indicate that 21 percent agreed that if the credit rating of their firm was to improve they would hold less cash, 29.40 percent agreed that there is easy access to Capital/Debt markets so they didn't need to hold a lot of cash and 14.20 percent agreed that costs of financial distress/Bankruptcy are high so they hold large cash balances to be in control. 35.3 percent of the respondents agreed that when in financial distress firms are more likely to use excess cash flows to increase cash holdings instead of paying down debt. The results further indicated that 21.80 percent were in agreement that they would likely reduce their cash holding if their debt levels reduced. The mean score for the response in this section was 1.98 which indicates that majority of the respondents disagreed with statements regarding influence of leverage on the cash holdings.

Table 6. Descriptive statistics of effect of leverage constructs

\begin{tabular}{|c|c|c|c|c|c|c|}
\hline Statement & $\begin{array}{l}\text { Strongly } \\
\text { Disagree }\end{array}$ & Disagree & Agree & $\begin{array}{l}\text { Strongly } \\
\text { Agree }\end{array}$ & Mean & $\begin{array}{l}\text { Std. } \\
\text { Dev }\end{array}$ \\
\hline If the credit rating of my firm was to improve I will hold less cash & $46.20 \%$ & $32.80 \%$ & $9.20 \%$ & $11.80 \%$ & 1.87 & 1.01 \\
\hline $\begin{array}{l}\text { There is easy access to Capital/Debt markets so I don't need to } \\
\text { hold a lot of cash }\end{array}$ & $2.50 \%$ & $68.10 \%$ & $10.10 \%$ & $19.30 \%$ & 2.46 & 0.83 \\
\hline $\begin{array}{l}\text { Costs of financial distress/Bankruptcy are high so I hold large } \\
\text { cash balances to be in control }\end{array}$ & $50.40 \%$ & $35.30 \%$ & $13.40 \%$ & $0.80 \%$ & 1.65 & 0.74 \\
\hline $\begin{array}{l}\text { When in financial distress firms are more likely to use excess cash } \\
\text { flows to increase cash holdings instead of paying down debt }\end{array}$ & $37.80 \%$ & $26.90 \%$ & $28.60 \%$ & $6.70 \%$ & 2.04 & 0.97 \\
\hline We will reduce our cash holding if our debt levels reduce & $47.90 \%$ & $30.30 \%$ & $9.20 \%$ & $12.60 \%$ & 1.87 & 1.03 \\
\hline Total & $36.96 \%$ & $38.68 \%$ & $14.10 \%$ & $10.24 \%$ & 1.98 & 0.92 \\
\hline
\end{tabular}

\subsection{Managerial Perspectives on Firm's Cash Holdings and Cash Flows}

Table 7 indicate that 42.0 percent agreed that firms with higher levels of internally generated cash flows tend to hold more cash, 36.2 percent agreed that the primary cause for a firm's excess cash balances is the accumulation of internally generated cash flows, and 25.20 percent agreed that financially constrained firms are more likely to save cash from internally generated cash flows to fund future investment opportunities. Also, 20.2 percent agreed that if they accumulated more debt, we would increase our cash holding. The mean score for responses for this section was 2.36 which indicates that minority of the respondents agreed cash flows had an influence on cash holdings.

Table 7. Descriptive statistics of cash flows constructs

\begin{tabular}{|c|c|c|c|c|c|c|}
\hline Statement & $\begin{array}{l}\text { Strongly } \\
\text { Disagree }\end{array}$ & Disagree & Agree & $\begin{array}{l}\text { Strongly } \\
\text { Agree }\end{array}$ & Mean & $\begin{array}{l}\text { Std. } \\
\text { Dev }\end{array}$ \\
\hline Firms with higher levels of internally generated cash flows tend to hold more cash & $3.40 \%$ & $54.60 \%$ & $36.10 \%$ & $5.90 \%$ & 2.45 & 0.66 \\
\hline $\begin{array}{l}\text { The primary cause for a firm's excess cash balances is the accumulation of } \\
\text { internally generated cash flows }\end{array}$ & $6.70 \%$ & $57.10 \%$ & $11.80 \%$ & $24.40 \%$ & 2.54 & 0.94 \\
\hline $\begin{array}{l}\text { Financially constrained firms are more likely to save cash from internally generated } \\
\text { cash flows to fund future investment opportunities }\end{array}$ & $12.60 \%$ & $62.20 \%$ & $7.60 \%$ & $17.60 \%$ & 2.30 & 0.91 \\
\hline If we accumulate more debt we will increase our cash holding & $13.40 \%$ & $66.40 \%$ & $12.60 \%$ & $7.60 \%$ & 2.14 & 0.74 \\
\hline Total & $9.03 \%$ & $60.08 \%$ & $17.03 \%$ & $13.88 \%$ & 2.36 & 0.81 \\
\hline
\end{tabular}

\subsection{Managerial Perspectives on Firm's Cash Holdings and Interest Rates}

Table 7 shows that 67.3 Percent agreed that they would hold large cash balances if interest rates are expected to rise, 68 percent agreed that if interest rates in the market were stable firms would hold less cash and 20.2 percent agreed that in times of fluctuations in interest rates they increase their holding of cash and marketable securities. 
The mean score for responses for this section was 2.60 which indicates that majority of the respondents agreed that interest rates was a major factor in on firm's cash holdings.

Table 7. Descriptive statistics of interest rates constructs

\begin{tabular}{|c|c|c|c|c|c|c|}
\hline Statement & $\begin{array}{l}\text { Strongly } \\
\text { Disagree }\end{array}$ & Disagree & Agree & $\begin{array}{l}\text { Strongly } \\
\text { Agree }\end{array}$ & Mean & $\begin{array}{l}\text { Std. } \\
\text { Dev }\end{array}$ \\
\hline I will hold large cash balances if interest rates are expected to rise & $5.00 \%$ & $27.70 \%$ & $55.50 \%$ & $11.80 \%$ & 2.74 & 0.73 \\
\hline If Interest rates in the market were stable firms would hold less cash & $0.00 \%$ & $31.90 \%$ & $48.70 \%$ & $19.30 \%$ & 2.87 & 0.71 \\
\hline $\begin{array}{l}\text { In times of fluctuations in interest rates, we increase our holding of } \\
\text { cash and marketable securities }\end{array}$ & $5.00 \%$ & $74.80 \%$ & $16.80 \%$ & $3.40 \%$ & 2.18 & 0.57 \\
\hline Total & $3.33 \%$ & $44.80 \%$ & $40.33 \%$ & $11.50 \%$ & 2.60 & 0.67 \\
\hline
\end{tabular}

\subsection{Managerial Perspectives on Firm's Cash Holdings and Industry Sector}

Table 8 indicates that 58.80 percent agreed that if their business involved huge outlay in capital assets (Plant equipment and technology) they could hold higher levels of cash, 64.70 Percent agreed that there if their firm were operating in a different industrial/ economic sector they would change their cash holding policy and 71.40 percent agreed that because their firm business is diversified they can hold less cash. The mean score for responses for this section was 2.67 which indicates that majority of the respondents agreed that industry sectors were a key driver of firm's cash holdings. The findings are similar to those by Opler et al. (1999), Saddour (2007) and Gill and Shah (2012).

Table 8. Descriptive statistics of industry sectors constructs

\begin{tabular}{|c|c|c|c|c|c|c|}
\hline Statement & $\begin{array}{l}\text { Strongly } \\
\text { Disagree }\end{array}$ & Disagree & Agree & $\begin{array}{c}\text { Strongly } \\
\text { Agree }\end{array}$ & Mean & $\begin{array}{l}\text { Std. } \\
\text { Dev }\end{array}$ \\
\hline $\begin{array}{l}\text { If our business involved huge outlay in capital assets (Plant equipment } \\
\text { and technology) we could hold higher levels of cash }\end{array}$ & $8.40 \%$ & $32.80 \%$ & $52.10 \%$ & $6.70 \%$ & 2.57 & 0.74 \\
\hline $\begin{array}{l}\text { If our firm was operating in a different industrial/ economic sector we } \\
\text { would change our cash holding policy }\end{array}$ & $0.00 \%$ & $35.30 \%$ & $64.70 \%$ & $0.00 \%$ & 2.65 & 0.48 \\
\hline Because our firm business is diversified we are able to hold less cash & $0.00 \%$ & $28.60 \%$ & $64.70 \%$ & $6.70 \%$ & 2.78 & 0.55 \\
\hline Total & $2.80 \%$ & $32.23 \%$ & $60.50 \%$ & $4.47 \%$ & 2.67 & 0.59 \\
\hline
\end{tabular}

\section{Conclusions and Recommendations}

This paper sought to examine the determinants of cash holdings among firms listed on Nairobi Securities Exchange where we adopted a manager's perspective to establish the factors that determines the optimal cash holdings. Our results reveal some important insights into cash holding among the firms studied. First, we conclude that managers strive to hold optimal levels of cash so as to reduce the opportunity costs of holding too much cash while also trying to balance the uncertainity that is associated with holding little amounts of cash consequently limiting the opportunity to undertake profitable opportunities when they arise. Secondly we conclude that most managers do not the view that their cash holding is influenced by investment opportunitie, leverage and size. We also conclude that with regard to the market-to-book value managers of firms choose to hold large amounts of cash so as to avoid the likely costs associated with financial distress or bankruptcy should they occur. Lastly, we establish that firms with higher levels of internally generated cash flows tend to hold more cash than are financially constrained firms.

In light of the above findings we therefore recommend that firms should strive to determine an optimal cash holding that suits their firm size, that takes into account is current and future investment opportunities as well as the likelihood of financial distress. Cash holdings thus acts as a cushion and buffer against uncertain business environments which firms are more susceptible to.

\section{Suggestions for Further Research}

From the results of our study there are various opportunities for further study in the cash holding space. Some of the results in this studies did not support previous findings on the study variables as predicted and will thus call for further analysis and investigation to understand the finding. Some of the areas to enrich research findings would be to bring in study variables that consider corporate governance attributes such as ownership concentration, board size and board independence. It would also be useful for a study to be extended to private firms to compare the results with the sample of public firms. Finally a comparative study can be done on the 
determinants of cash holdings in multiple emerging market countries and the data compared.

\section{References}

Almeida, H., Campello, M., \& Weisbach, M. (2004). The cash flow sensitivity of cash. Journal of Finance, 59, 1777-2084. https://doi.org/10.1111/j.1540-6261.2004.00679.x

Al-Najjar, B. (2013). The financial determinants of corporate cash holdings: Evidence from some emerging markets. International Business Review, 22(1), 77-88. https://doi.org/10.1016/j.ibusrev.2012.02.004

Al-Najjar, B., \& Belghitar, Y. (2011). Corporate cash holdings and dividend payments: Evidence from Simultaneous Analysis. Managerial \& Decision Economics, 32(4), 231-241. https://doi.org/10.1002/mde.1529

Chen, Y. (2008). Corporate governance and cash holdings: Listed new economy versus old cconomy firms. Corporate Governance: An International Review, 16(5), 430-442. https://doi.org/10.1111/j.1467-8683.2008.00701.x

Dittmar, A. K., \& Duchin, R. (2010). The dynamics of cash. Ross School of Business Paper No. 1138. https://doi.org/10.2139/ssrn.1569529

Dittmar, A., \& Mahrt-Smith, J. (2007). Corporate governance and value of cash holdings. Journal of Financial Economics, 83, 599-634. https://doi.org/10.1016/j.jfineco.2005.12.006

Dittmar, A., Mahrt-Smith, J., \& Servaes, H. (2003). International corporate governance and corporate cash holdings. Journal of Financial and Quantitative Analysis, 38(1), 111-133. https://doi.org/10.2307/4126766

Ferreira, M. A., \& Vilela, A. S. (2004). Why do firms hold cash? Evidence from EMU Countries. European Financial Management, 10(2), 295-319. https://doi.org/10.1111/j.1354-7798.2004.00251.x

Field, A. (2000). Discovering Statistics Using SPSS For Windows. London-Thomas Oaks -New Delhi: Sage Publications.

Gill, A., \& Shah, C. (2012). Determinants of corporate cash holdings: Evidence from Canada. International Journal of Economics and Finance, 4(1), 70. https://doi.org/10.5539/ijef.v4n1p70

Gryglewicz, S. (2011). A Theory of corporate financial decisions with liquidity and solvency concerns. Journal of Financial Economics (JFE), 99(2). https://doi.org/10.1016/j.jfineco.2010.09.010

Kalcheva, I., \& Lins, K. V. (2003). International evidence on cash holdings and expected managerial agency problems. Review of Finance, 20, 1087-1112.

Morais, F., \& Silva, P. (2013). Determinants of cash holdings in the accommodation industry. Tourism and Hospitality International Journal, 1, 95-136.

Mugenda, O. M., \& Mugenda, A. G. (2003). Research Methods: Quantitative and Qualitative Approaches. Nairobi: Acts Press

Opler, T., Pinkowitz, L., Stulz, R., \& Williamson, R. (1999). The determinants and implications of corporate cash holdings. Journal of Financial Economics, 52, 3-46. http://dx.doi.org/10.1016/S0304-405X (99)00003-3.

Pinkowitz, L., Stulz, R., \& Williamson, R. (2006). Does the contribution of corporate cash holdings and dividends to firm value depend on governance? A cross-country analysis. Journal of Finance, 61, 2725-2751. https://doi.org/10.1111/j.1540-6261.2006.01003.x

Powell, G. E., \& Baker, H. (2010). Management views on corporate cash holdings. Journal of Applied Finance, 20(2), 155-168.

Saddour, K. (2006). The determinants and the value of cash holdings: Evidence from French Firms. CEREG, 1-33. Retrieved from http://www.dauphine.fr/cereg/cahiers_rech/cereg200606.pdf

Venkiteshwaran, V. (2011). Partial adjustment toward optimal cash holding levels. Review of Financial Economics, 20(3), 113-121. https://doi.org/10.1016/j.rfe.2011.06.002

\section{Copyrights}

Copyright for this article is retained by the author(s), with first publication rights granted to the journal.

This is an open-access article distributed under the terms and conditions of the Creative Commons Attribution license (http://creativecommons.org/licenses/by/4.0/). 